20. Агрокліматичний довідник по Львівській області (1986-2005рр.) / ред. I.3. Федик, Т.І. Адаменко; Львівський РЦГМ. - Львів: Атлас, - 2013. - 218 c.

21. Геренчук К.I. Природа Львівської області / К.І. Геренчук. - Львів: Видавництво Львівського університету, 1972. - $152 \mathrm{c}$.

22. ДСТУ Б.В.2.1.-3-96 (ГОСТ 30416-96) Ірунти. Лабораторні випробовування. Загальні положення.
23. ГОСТ 5180-84. Грунты. Методы лабораторного определения физических характеристик.

Рецензент: к.т.н., с.н.с. М.В. Чорний, Національна академія сухопутних військ імені гетьмана Петра Сагайдачного, Львів.

ЭКСПЕРИМЕНТАЛЬНЫЕ ИССЛЕДОВАНИЯ ПРОЦЕССА ВЗАИМОДЕЙСТВИЯ ДВИЖИТЕЛЕЙ БОЕВЫХ БРОНИРОВАННЫХ МАШИН С ДЕФОРМИРУЕМЫМИ ГРУНТОВЫМИ ПОВЕРХНОСТЯМИ

\author{
Я.С. Мищенко, А.Н. Куприненко
}

Рассмотрена проблема определения параметров движителя перспективных боевых бронированных машин с учетом особенностей изменения механических характеристик почвы. Показано несовершенство существующих научно-методических подходов. Экспериментально подтверждено адекватность предложенных аналитических зависимостей определения параметров движителей боевых бронированных машин.

Ключевые слова: боевая бронированная машина,параметри движителя, грунтовая поверхность.

\title{
EXPERIMENTAL STUDY OF INTERACTION DRIVER OF ARMORED COMBAT VEHICLES WITH DEFORMABLE GROUND SURFACES
}

\author{
Y. Mischenko, O. Kuprinenko
}

The problem of the parameters definition of the perspective armored combat vehicles propeller considering the changes in the mechanical characteristics of the soil is reviewed. The inadequacy of existing scientific and methodological approaches is shown. Experiments confirmed the adequacy of the proposed analytical dependences of parameters determining the propulsion of armored combat vehicles.

Key words: armored combat vehicle, propeller, mechanical characteristics of the soil.

УДК 007.52; 623.4.016

Ю.В. Мирончук

Національна академія сухопутних військ імені гетьмана Петра Сагайдачного, Львів

\section{СУЧАСНИЙ СТАН ТА ПЕРСПЕКТИВИ РОЗВИТКУ НАЗЕМНИХ МОБІЛЬНИХ РОБОТОТЕХНІЧНИХ КОМПЛЕКСІВ ДЛЯ СУХОПУТНИХ ВІЙСЬК ЗБРОЙНИХ СИЛ УКРАЇНИ}

У статті розглянуто зміни характеру ведення збройної боротьби, їх вплив на розвиток наземних мобільних робототехнічних комплексів. Проведено аналіз стану розвитку наземних мобільних робототехнічних комплексів, обтрунтовано необхідність побудови їх типажу для Сухопутних військ Збройних Сил Украӥни.

Ключові слова: наземний мобільний робототехнічний комплекс, мобільний робот, типаж.

\section{Ветуп}

Постановка проблеми та аналіз останніх досліджень та публікацій. Характер ведення збройної боротьби за останні десятиліття значно змінився. За рахунок нових можливостей систем розвідки, управління і забезпечення відбувся перехід від лінійної взаємодії великих військових формувань до маневреної війни, локальних збройних конфліктів 3 широким застосуванням невеликих за чисельністю бойових груп $[1,2]$. 
Зміни характеру ведення збройної боротьби характеризуються широким використанням асиметричних і непрямих дій, високоточної зброї, високоманеврених безконтактних дій міжвидових угруповань військ, сил спеціальних операцій. Суттєві зміни характеру ведення збройної боротьби також обумовлені невизначеністю, що викликана розмитістю розділювальної межі між миром та війною, цивільними та військовими, спрямованістю дій на всю глибину протиборчих сторін, на їх політичну інфраструктуру та суспільство, психологічним впливом та маніпулюванням засобами масової інформації з метою зміни суспільної думки в країні та світі $[3,4]$.

Досвід останніх воєнних конфліктів свідчить, що внаслідок зростання можливостей засобів ураження, зокрема, підвищення точності, дальності, швидкості та вибірковості їх впливу, виникають складності при використанні існуючих зразків бойових броньованих машин (ББМ). Вони пов'язані, насамперед, $з$ недостатнім рівнем їх захищеності від сучасних засобів ураження, високою ймовірністю ураження особового складу [5].

Одним 3 найбільш перспективних шляхів зменшення втрат особового складу є використання наземних мобільних робототехнічних комплексів (НМРТК).

За результатами проведеного аналізу встановлено, що НМРТК використовувались у збройних конфліктах в Іраку (2003-2011рp.) та Афганістані (2001-2014 рр.) для пошуку та знешкодження вибухових пристроїв, обстеження будівель, печер, замаскованих складів зброї та боєприпасів [6].

Розвитку НМРТК також сприяли такі фактори, як:

різкий стрибок в області високих технологій за допомогою відеокамер та сенсорів робототехнічні комплекси "бачать" обстановку, а за допомогою обчислювальної системи - самостійно приймають рішення або пропонують прийняти рішення оператору;

перехід на професійні армії - вартість підготовки солдата-професіонала зростає в рази, а тому завдання щодо зменшення бойових втрат особового складу стає першочерговим.

Позитивні результати застосування НМРТК у воєнних конфліктах стали поштовхом для нарощування зусиль урядами таких країн як США, Великобританія, Канада, Ізраїль, Франція, Росія, Китай, Іран та Індія щодо збільшення фінансування та інтенсифікації наукової та науково-технічної діяльності в галузі військової робототехніки. Станом на сьогоднішній день більше десятка країн виготовляють НМРТК для власних потреб та на експорт. Серед них є й сусідні країни - Білорусь, Польща, Росія. Беззаперечним лідером за різноманітністю, кількістю моделей та досвідом застосування НМРТК є США [7].
Проте в Збройних Силах (3С) України НМРТК відсутні. Їх розробка в Україні має ініціативний, поодинокий характер [8, 9]. Розробники, якими, як правило, є невійськові підприємства, недостатньо враховують особливості ведення сучасної збройної боротьби, специфіку бойових завдань, які покладаються на НМРТК. При виборі компонувальних рішень та параметрів НМРТК розробники, як правило, опираються на власний не військовий досвід або використовують принципи будови існуючих зразків екіпажної військової техніки. Це не завжди позитивно впливає на правильність прийнятих рішень. Основною причиною ситуації, що виникла, $\epsilon$ безсистемність, недостатня ефективність воєнно-наукових обгрунтувань.

Виникає необхідність проведення досліджень, спрямованих на розробку науково-методичного апарату, який дозволить обгрунтувати раціональний склад номенклатури НМРТК для потреб Сухопутних військ ЗС України.

Метою статті $\epsilon$ аналіз сучасного стану та перспектив розвитку НМРТК.

\section{Виклад основного матеріалу}

Дослідження 3 розробки науково-методичного апарату побудови типажу НМРТК доцільно почати 3 основних положень понятійного апарату, класифікації НМРТК, аналізу стану їх розвитку.

Під типажем НМРТК розуміється раціональний склад їх номенклатури, систематизованих та уніфікованих за функціонально-конструктивними ознаками, значеннями параметрів, що забезпечують перспективну потребу військ [10].

НМРТК - сукупність мобільного робота, системи дистанційного керування та засобів забезпечення експлуатації робота [11].

Мобільний робот - дистанційно керований оператором самохідний робототехнічний засіб.

Робототехнічний засіб - засіб, який виконує функції, визначені види робіт або операції без безпосередньої участі людини.

Для систематизації існуючих сьогодні НМРТК їх класифікують за [12]:

1. Масою:

міні (до 2 кг);

легкі (2-20 кг);

середні (20-200 кг);

важкі (200 кг - 2 т);

надважкі (понад 2 т).

2. Призначенням:

бойові;

бойового забезпечення;

спеціально-технічного забезпечення;

тилового забезпечення.

3. Типом управління:

автономні;

програмовані; 
керовані;

супервізорні;

комбіновані.

4. Типом рушія:

гусеничні;

колісні;

комбіновані;

крокуючі.

5. Ступенем функціональності:

багатоцільові;

спеціалізовані.

6. Типом силової установки:

електричний;

двигун внутрішнього згоряння;

гібридний.

Найбільш поширеною є класифікація НМРТК за масою. Вона дає можливість визначити спосіб доставки мобільного робота до місця виконання завдань, характеризує специфіку завдань, які можуть покладатися на НМРТК.

До класу "міні" відносяться НМРТК, які використовуються на дистанціях до 200 м для ведення розвідки та доставки невеликих вантажів 3 тривалістю роботи до 2 год. Малі розміри і мала маса дозволяє військовослужбовцю легко переносити такий мобільний робот у кишені. Завдяки протиударним властивостям корпуса військовослужбовець може самостійно закинути його на відстань до 40 м або, наприклад, у вікно будівлі. Управління такими роботами досить просте i може здійснюватись зі звичайного смартфона за допомогою спеціального програмного забезпечення.

До класу "легкі" відносяться НМРТК, які дистанційно керуються на відстані до 1000 м. Масогабаритні показники роботів цього класу дозволяють переносити їх, як рюкзак, на спині. Призначення залежно від розмірів - ведення розвідки, доставка вантажів масою до 5 кг, а у разі встановлення маніпулятора - знешкодження вибухових пристроїв. Тривалість активної роботи - від 2 до 6 год залежно від розмірів та ємності акумуляторів.

НМРТК середнього класу можуть використовуватися для евакуації поранених, транспортування вантажів масою до 250 кг, ведення розвідки, патрулювання місцевості, знешкодження вибухових пристроїв та ведення вогню. Такі роботи можуть бути перенесені силами кількох військовослужбовців або транспортовані легким автомобілем. Потужність силової установки та розміри мобільного робота дозволяють встановлювати на ньому різне обладнання сенсори, тепловізори, лазерні далекоміри, гранатомети, стрілецьку зброю, потужні маніпулятори та ін.

Кількість завдань, які можуть виконувати важкі НМРТК, не менша, ніж у НМРТК середнього класу. Представники цього класу зазвичай комплектуються дизельними двигунами внутрішнього згоряння, що забезпечує їм значну тривалість роботи (до 2-х діб) та можливість самостійно висуватись в район призначення.

Основне призначення більшості представників надважкого класу - пророблення проходів у мінновибухових загородженнях за допомогою додатково встановленого трала та бульдозерного відвалу.

Аналіз характеристик 58-ми розроблених за останніх два десятиліття моделей НМРТК показує, що 53\% всіх моделей складають середні (19\%) та важкі (34\%) мобільні роботи (рис. 1), а найменшу кількість (13\%) - надважкі [13, 14].

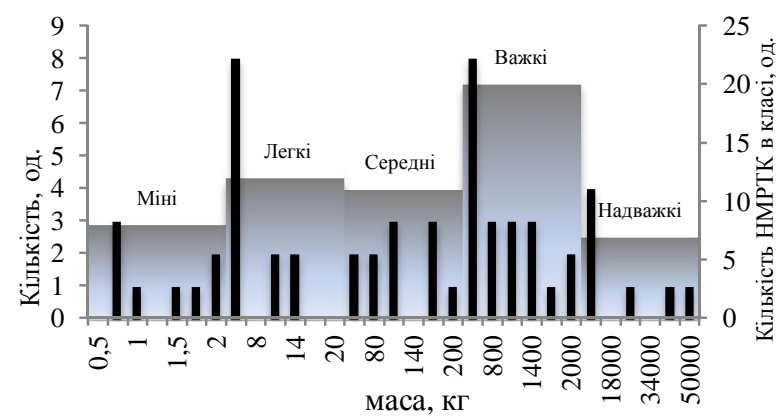

Рис. 1. Розподіл кількості моделей НМРТК за масою

Зазначені показники підтверджують, що потреба в машинах надважкого класу значно нижча, ніж у менших, легших, а, відповідно, і дешевших НМРТК.

Найчастіше виробники виготовляють НМРТК, які можуть виконувати декілька функцій, тобто багатоцільові. Загальна частка багатоцільових НМРТК є більшою відносно спеціалізованих (59\% до 41\%). Як видно 3 рис. 2, кількість багатоцільових НМРТК в 2,3 - 10 разів перевищує кількість спеціалізованих в класі від 2 до 2000 кг. Серед спеціалізованих в класі "міні" та "легкі" абсолютну більшість складають НМРТК, які виконують завдання розвідки та спостереження. Більшість середніх та важких спеціалізованих НМРТК призначені для виконання транспортних завдань - доставка військового майна, зброї, боєприпасів та евакуація поранених. У надважкому класі всі спеціалізовані НМРТК призначені для пророблення проходів у мінно-вибухових загородженнях.

Найбільший модельний ряд багатофункціональних НМРТК в середньому класі представила американська компанія QinetiQ North America моделлю MAARS (Modular Advanced Armed Robotic System) та серією моделей Talon. Розглянемо модель MAARS, яка $є$ яскравим прикладом багатоцільових НМРТК [15]. Мобільний робот MAARS побудований за модульним принципом, що дає змогу оператору перед виконанням завдання швидко встановити на базове гусеничне шасі все необхідне обладнання. На шасі можуть бути встановлені:

маніпулятор вантажопідйомністю до 54 кг;

модуль озброєння з 7,62-мм кулеметом М240B (450 набоїв) та 4-ма 40-мм гранатометами М203 (4 гранати). 


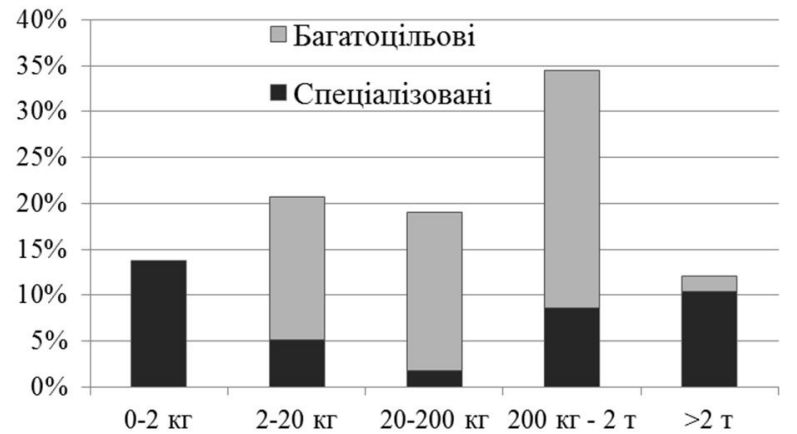

Рис. 2. Розподіл НМРТК за функціональністю

Крім того, на гусеничному шасі MAARS встановлена система супутникової навігації, камери денного i нічного бачення, тепловізор, лазерний далекомір, а також засоби зв'язку та обміну даними. Також на нього можуть бути встановлені лазер, який тимчасово засліплює очі, потужна акустична система, а гранатомет має можливість стріляти димовими гранатами і гранатами зі сльозогінним газом. При повній масі 167 кг MAARS може тягнути за собою до 140 кг корисного навантаження. Максимальне віддалення мобільного робота від пульта керування складає 1000 м на відкритій місцевості, а наявна ємність акумуляторів забезпечує максимальну тривалість роботи без підзарядки до 12 год.

Таким чином, зазначене обладнання обумовлює широкий спектр завдань, які можуть покладатися на MAARS: розвідка, ведення вогню, знешкодження мінно-вибухових пристроїв, доставка вантажів, евакуація поранених.

До інших важливих параметрів НМРТК відносяться тип рушія та силової установки. Аналіз типів рушія моделей всіх класів показав, що кількість колісних та гусеничних рушіїв майже рівна (41\% і $45 \%$ відповідно). 14\% припадає на комбінований рушій, який передбачає використання як гусениць, так і коліс (рис. 3).

Як видно з рис. 3, гусеничний рушій переважає колісний у легкому, середньому та надважкому класі НМРТК, а у важкому класі кількість гусеничних i колісних рушіїв майже рівна. Переважання гусеничного рушія над колісним та наявність комбінованих рушіїв підтверджує, що НМРТК повинні володіти високою профільною та опорною прохідністю [11]. Без сторонньої допомоги вони здатні самостійно пересуватись і успішно виконувати покладені на них завдання.

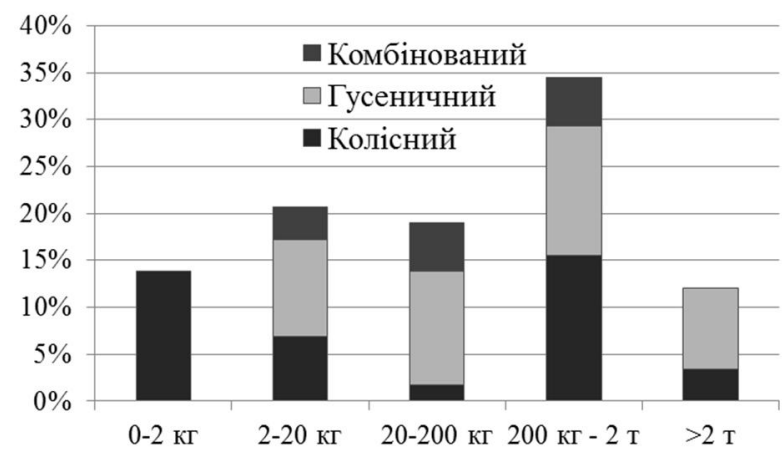

Рис. 3. Розподіл НМРТк за типом рушія
Гістограма, наведена на рис. 4, показує, що електрична силова установка є найбільш поширеною, за винятком надважкого класу, де переважають двигуни внутрішнього згоряння, які також складають значну частину важкого класу. Гібридні силові установки зустрічаються тільки у важкому та надважкому класах.

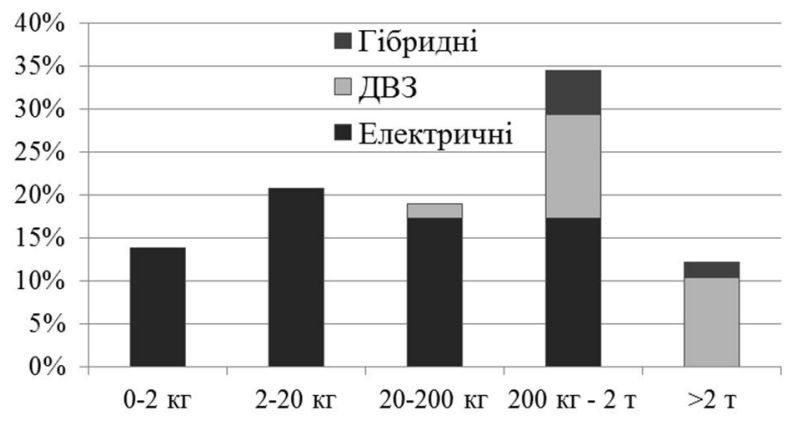

Рис. 4. Розподіл НМРТК за типом силової установки

Широке застосування електричної силової установки пояснюється іiі високими показниками коефіцієнта корисної дії, керованістю, простотою підведення енергії. Обмеження у застосуванні гібридних установок обумовлюються їх високою вартістю, складністю та збільшеними габаритами.

\section{Висновки}

Досвід застосування НМРТК у сучасних воєнних конфліктах та прогнози військових експертів свідчать про актуальність їх розробки для вирішення бойових завдань, які покладаються на підрозділи Сухопутних військ ЗС України. Це дозволяє суттєво зменшити втрати особового складу від сучасних засобів ураження.

Але процес розробки НМРТК в Україні $\epsilon$ безсистемним та характеризується недостатньою ефективністю воєнно-наукових обгрунтувань. Виникає необхідність проведення досліджень, спрямованих на розробку науково-методичного апарату, який дозволить обгрунтувати типаж НМРТК для потреб Сухопутних військ 3С України. Зазначений науковометодичний апарат повинен враховувати специфіку завдань, які покладаються на НМРТК, можливості їх уніфікації з метою зменшення витрат на виробництво та експлуатацію.

На початковому етапі цих досліджень проведено аналіз стану розвитку НМРТК, сформульовано основні положення понятійного апарату, уточнено класифікацію.

\section{Список літератури}

1. Хамзатов М.М. Влияние концепции сетецеентрической войны на характер современных операций / М.М. Хамзатов. // Военная мыслль. - 2006. -№ 7. - С. 13-17.

2. Джура О. Десятиліття війни. Стратегічні уроки військових операчій США у ХХІ столітті / О. Джура. // Defense express. Экспорт оружия и оборонный комплекс Украины. - 2014. - № 2. - C. 50-60. 
3. Герасимов В.В. Роль Генерального итаба в организации обороны страны в соответствии с новым Положением о Генеральном итабе, утвержденным президентом Российской Федерации (тезисы) / В.В.Герасимов. // Вестник Академии военных наук. 2014. - № 1. - C. 14-22.

4. Хоффман Ф. Гибридные угрозы: переосмысление изменяющегося характера современных конфликтов / Фрэнк Хоффман. // Геополитика. Информачионноаналитическое издание. - 2013. - № 21. - С. 45-62.

5. Купріненко О.М. Обгрунтування принципів формування перспективних типів бойових броньованих машин / О.М. Купріненко. // Системи озброєння і військова техніка. 2012. - № 4. - C. 40-46.

6. Carafano J.J. The Pentagon's Robots: Arming the Future / J.J. Carafano, A. Gudgel. // Backgrounder. - 2007. № 2093. - P. 1-6.

7. Сердюк О. Військові роботи: виклики сьогодення [Електронний ресурс] / Олексій Сердюк // Інформачійноконсалтингова компанія «DEFENSE EXPRESS». - 2016. Pежим досmyny: http://defence-ua.com/index.php/statti/661viyskovi-roboty-vyklyky-sohodennya.

8. Згуреи С.Г. Инженеры «Азова»: от БМПТ до роботов / С.Г. Згуреи Танки. Боевые бронированные машины / С.Г. Згурец. - Київ: Издательский дом «АДЕФ Украина», 2016. - (Оружие Украины). - (Блеск и скрежет стали. Уроки войны; т. 1). - С. 152-153.

9. У Львові презентували робота-розвідника для АТО [Електронний ресурс] // УНІАН. - 2014. - Режим docmyny: http://army.unian.ua/988181-u-lvovi-prezentuvalirobota-rozvidnika-dlya-ato.html.
10. Разработка типажей на изделия общей техники. Рекомендации: РВ 50-60-51-88. - Москва: Государственный комитет СССР по стандартам. - 1988. - 13 с

11. Мобильные робототехнические комплексы для проведения аварийно-спасательных работ и пожаротушения. Классификачия. Общчие технические требования. Методы испьтаний: ГОСТ Р 54344-2011. - Москва: Стандартинформ, 2012. - 31 с. - (Национальный стандарт Российской Федерачии).

12. Юревич Е.И. Военная робототехника / Е.И. Юревич // Основы робототехники: учеб. пособие. 3-е изд. / Е.И. Юревич. - Санкт-Петербург: БХВПетербург, 2010. - С. 321-323.

13. Compendium Ground Robotics Supplement to Armada Issue 5/2014 Volume 38, Issue No. 5 [Електронний pecypc] // Armada. - 2014. - Режим доступу: http://www.armadainternational.com/assets/images/pdf/5-

Land_low_res.pdf.

14. Басов А. Большой каталог роботов [Електронний ресурс] / Алексей Басов // Defence.ru Режим доступу до ресурсу: http://defence.ru/document/126. 15. Modular Advanced Armed Robotic System (MAARS) [Електронний ресурс] // QinetiQ North America-Pежим docmyny: https://www.qinetiq-na.com/wp-

content/uploads/brochure_maars.pdf.

Рецензент: д.т.н., с.н.с. О.М. Купріненко, Національна академія сухопутних військ імені гетьмана Петра Сагайдачного, Львів.

\title{
СОВРЕМЕННОЕ СОСТОЯНИЕ И ПЕРСПЕКТИВЫ РАЗВИТИЯ НАЗЕМНЫХ МОБИЛЬНЫХ РОБОТОТЕХНИЧЕСКИХ КОМПЛЕКСОВ ДЛЯ СУХОПУТНЫХ ВОЙСК ВООРУЖЕННЫХ СИЛ УКРАИНЫ
}

\author{
Ю.В. Мирончук
}

В статье рассмотрены изменения характера ведения вооруженной борьбы, их влияние на развитие наземных мобильных робототехнических комплексов. Проведено анализ состояния развития наземных мобильных робототехнических комплексов, обоснована необходимость построения их типажа для Сухопутных войск Вооруженных Сил Украины.

Ключевые слова: наземный мобильный робототехнический комплекс, мобильный робот, типаж.

\section{CURRENT STATE AND DEVELOPMENT PROSPECTS OF UNMANNED GROUND VEHICLES FOR THE ARMY OF THE ARMED FORCES OF UKRAINE}

Y. Myronchuk

The article examines the changing nature of warfare, its influence on the development of unmanned ground vehicles. It provides the analysis of unmanned ground vehicles status, grounds the necessity to construct the range of types of unmanned ground vehicles for the Army of the Armed Forces of Ukraine.

Key words: unmanned ground vehicle, mobile robot, range of types. 